\title{
Anthropometric Comparison of Three-Year-Old Nigerian Child and Crash Dummies
}

\author{
Ibrahim Abdullahi Rafukka ${ }^{1,2}$, Barkawi Bin Sahari ${ }^{1}$, Abdulaziz Nuraini ${ }^{1}$, \\ Arumugam Manohar ${ }^{3}$ \\ ${ }^{1}$ Department of Mechanical and Manufacturing Engineering, Faculty of Engineering, \\ Universiti Putra Malaysia, Serdang, Malaysia \\ ${ }^{2}$ Department of Mechanical Engineering, Bayero University, Kano, Nigeria \\ ${ }^{3}$ Department of Orthopaedic Surgery, Faculty of Medicine and Health Sciences, \\ Universiti Putra Malaysia, Serdang, Malaysia \\ Email: *ibrahimrafukka@yahoo.com
}

Received 4 May 2016; accepted 12 July 2016; published 15 July 2016

Copyright (C) 2016 by authors and Scientific Research Publishing Inc.

This work is licensed under the Creative Commons Attribution International License (CC BY). http://creativecommons.org/licenses/by/4.0/

(c) (7) Open Access

\begin{abstract}
In this work, anthropometric data measured from three-year-old Nigerian child were compared with United States anthropometric database collected by Snyder, 1977 which formed the basis of US anthropometry used today. Further comparison was also carried out with the dimensions of crash dummies: Hybrid III three-year-old (HIII 3YO) and Q3s dummies in order to determine the validity of using such crash dummies for safety evaluation of cars and child restraint systems (CRS) used for Nigerian children. Anthropometric survey was performed on 30 Nigerian children aged 2.5 to 3.5 years old. Twenty three standard measurements were taken from each child including the weight, height and circumferences etc. Various percentiles mean and standard deviation values were obtained and compared with international database. As observed, the dimensions of three-year-old Nigerian child appeared to be about $25 \%$ lower than US data reported by Snyder. Significant difference was also found between the dimensions of three-year-old Nigerian child and crash dummies. This study provides the external dimensions of 3-year-old Nigerian child that could be used for crash dummy and CRS design.
\end{abstract}

\section{Keywords}

Anthropometry, Crash Dummies, Child Restraint System, Measurement, Vehicle Safety

\footnotetext{
${ }^{*}$ Corresponding author.
}

How to cite this paper: Rafukka, I.A., Sahari, B.B., Nuraini, A. and Manohar, A. (2016) Anthropometric Comparison of Three-Year-Old Nigerian Child and Crash Dummies. Journal of Transportation Technologies, 6, 192-199. 


\section{Introduction}

Anthropometry is the measurement of human size: shape, dimensions, weight and physical capabilities. Body size, shape, mass and strength are critical in the design of product with which people interact. It is applicable in seat design, vehicle interior layout and development of crash dummies. Accurate body shape is necessary for designing correct child restraint system (CRS) for children. It is not possible to create a single human body model to represent all population. This is because human being is unique creature; any person has his own anthropometry and mechanical characteristics.

Development of crash dummy models requires knowledge of geometry and the external dimensions of human being it represents in sitting and standing posture for rear passenger and pedestrian respectively. The vehicle and safety systems used in developing countries were evaluated using crash dummies of other population anthropometry. Most commonly used Child dummy models are three- and six-year olds in crash analysis. Very few data exist on child segment anthropometry and the ones available were based on United States and European children, and mostly out dated, but none represents African child talk less of Nigerian alone. The only recent comprehensive anthropometric data of children were carried out in 70’s by university of Michigan Transportation Research Institute (UMTRI) by research team led by Snyder. This forms the basis of most US contemporary child body dimensions [1].

There are some efforts of comparing anthropometry of some population to crash dummies development. Serre et al. [2] compares the anthropometry of three-year-old and six-year-old French children with crash dummies. The measurement was performed on 70 and 80, three-year-old (3YO) and six-year-old (6YO) children respectively. The dimensions of French children were found to be $12 \%$ higher than other anthropometries. Other authors compared $50^{\text {th }}$ hybrid III dummy with adult Chinese occupant [3] and United States adult [4] with the aim of assessing their differences in anthropometries. Nigeria is the number one car buyer, highest economy and most populous country in Africa with an average of 70,000 cars sold annually and with an average of 1 vehicle to every 12 citizens [5]. It is imperative to consider this population in evaluation of vehicle crashworthiness especially for child occupants. To the best of author's knowledge, there is no research that considers the validity of using crash dummies on African population. To study this scenario anthropometric data are needed and to date no comprehensive anthropometric data described the dimensions of African population for crash dummy development.

Child vehicle safety has been given much concern recently by vehicle developers, researchers and society. Despite occupant safety systems available, child protection in vehicle crashes is still not optimum. It was recently shown that children 14 years and younger account for 3\% of total traffic fatalities in the United States [6]. This percentage is expected to be higher in developing countries with their failing infrastructure and poor or no safety regulations. For example African region possesses only $2 \%$ of the world's vehicles but it contributes $16 \%$ to the global deaths. Children aged 0 to 4 years were shown to account for $3.4 \%$ of the traffic death in 12 African countries [7]. Finite element (FE) modelling remains the most efficient tool to assess occupant injury risk and evaluate crash safety systems. Current FE models are limited to certain population anthropometry. Research on crash dummy development was recently focused on vulnerable population such as children especially obese, elderly, and pregnant women. Child occupants from developing countries like Nigeria need to be included in that population. In this work, brief survey has been performed to provide body segment dimensions of $3 \mathrm{YO} \mathrm{Ni}-$ gerian children. The aim was to compare these dimensions with crash dummies in order to determine whether they correspond with child dummies used in crashworthiness assessment of vehicles and CRS used by this population.

\section{Hybrid III 3 YO and Q3s Dummies}

Hybrid III 3YO dummy shown in Figure 1(a) was based on US child anthropometry collected in 1980's while Q-dummies are based on US, Europe and Japanese combined anthropometry (CANDAT DATABASE) [8]. The two dummies differ in biofidelity, while US dummies concerned with head, neck and chest biofidelity for frontal impact, the Q-dummies have the requirements of abdomen, shoulder and pelvis for frontal and side impacts. Q3s shown in Figure 1(b) is used in side impact assessment. Both dummies, though representing the same age group have different body structural design, size and weight as they are produced in different countries by different companies. Q dummies were developed by the International Child Dummy Working Group and the TNO Crash Safety Research Centre. The 3YO child Hybrid III dummy was developed by humanetics in 1990’s now Liver 


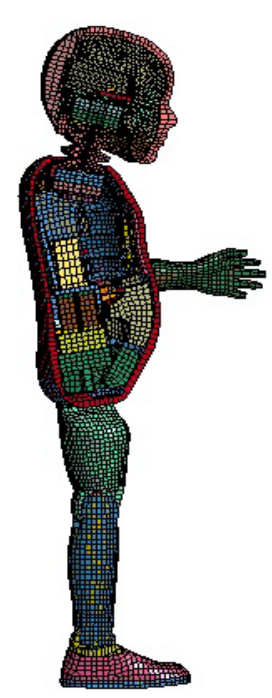

(a)

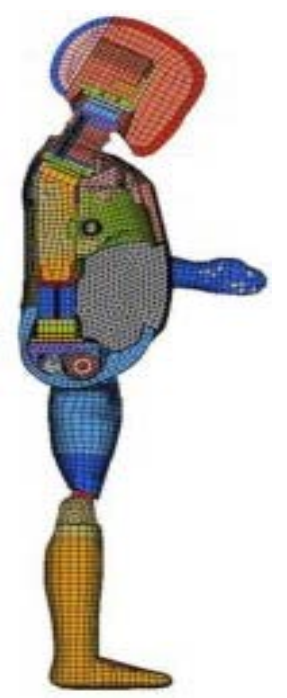

(b)

Figure 1. Hybrid III 3YO child dummy FE model (a) and Q3s child dummy FE model (b).

more Software Technology Corporation (LSTC) in conjunction with National Highway Traffic Safety Administration (NHTSA) and SAE Biomechanics Committees.

\section{Anthropometric Data Collection}

Due to the public health problem of malnutrition and other environmental, social and economic factors confronting African developing nations, the anthropometries of children differ significantly from that of developed nations. Subjects used in the present cross sectional study were mainly from Northern Nigerian Hausa tribe which constitute the largest ethnic group in West Africa with 22.5 million people in Nigeria alone [9].

Nigerian children were measured in order to obtain the external dimensions of each body segment. Thirty children aged 2.5 - 3.5 years were measured to determine the anthropometric dimensions. The subjects were sampled from the population of healthy children brought to nursery school and immunization clinic. The well being of the subject was obtained from mother or care givers. Consent of parents was obtained that their ward should be used as subject in the measurement. Measuring time was kept as small as possible usually 20 minutes and data anonymity has been respected. Date of birth was recorded for the calculation of the subject age.

The methods applied were similar to standard of measurement used by UMTRI [10]. Measurements have been taken in both standing and sitting postures. In standing the subject stands erect on horizontal surface against the wall with hands hanging down. For sitting, he sat erect on horizontal surface. Measurement was done without shoes and with light clothes. The sample sex ratio was 15 boys 15 girls. Mechanical instruments used include: anthropometer, sliding calliper and tape measure of $1 \mathrm{~mm}$ accuracy. There are 23 standard dimensions required to document child size used in crash dummy design. These dimensions in standing and sitting posture are as shown in Figure 2.

\section{Three-Year-Old Nigerian Child Anthropometric Data}

Table 1 shows dimensions of children aged around 3 years. Descriptive statistical analysis has been carried out using Statistical Package for Social Sciences (SPSS) software. The dimensions are in $\mathrm{cm}$ and the weight in $\mathrm{kg}$. Student independent t-test was conducted to determine the influence of gender. P-value shows that the difference in the means is not significant as such the data was merged without any distinction between male and female subjects.

\subsection{Comparison of 3YO Nigerian Child Dimensions with Other Anthropometric Studies}

To the best of author's knowledge no study gives detail anthropometric dimensions of 3YO Nigerian children that are sufficient for crash dummy design. The only data available indicates stature and weight of children 

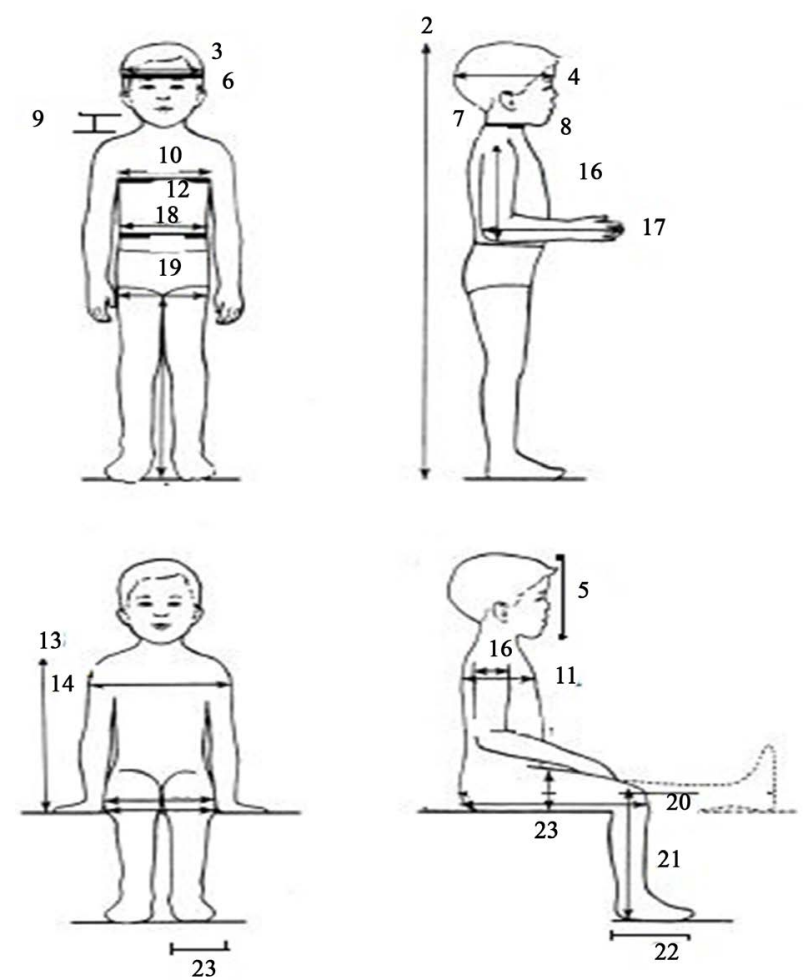

Figure 2. Measured child body dimensions (as defined in Table 1).

Table 1. Anthropometric dimensions of three year old Nigerian child.

\begin{tabular}{ccccccccccc}
\hline Measurement location & Dimension & Min & $5^{\text {th }}$ & $25^{\text {th }}$ & $50^{\text {th }}$ & $75^{\text {th }}$ & $95^{\text {th }}$ & Max & Mean & SD \\
\hline 1 & Weight & 9.0 & 9 & 10.3 & 12.0 & 13.3 & 15.5 & 16.0 & 12.2 & 1.8 \\
2 & Height & 73.8 & 75.0 & 83.0 & 87.0 & 91.1 & 98.2 & 98.5 & 87.0 & 5.9 \\
3 & Head breadth & 12.5 & 12.5 & 13.0 & 13.5 & 14.1 & 15.2 & 15.5 & 13.7 & 0.7 \\
4 & Head length & 16 & 16.3 & 17.1 & 18 & 14.1 & 15.2 & 19 & 17.7 & 0.7 \\
5 & Head height & 15.5 & 15.5 & 22.3 & 19 & 19.0 & 21.6 & 22.3 & 18.3 & 1.6 \\
6 & Head circumference & 45.0 & 45.6 & 47.0 & 48.3 & 49.2 & 51.1 & 51.8 & 48.3 & 1.6 \\
7 & Neck breadth & 6.5 & 10.0 & 7.9 & 8.5 & 9.0 & 9.7 & 10 & 8.3 & 0.9 \\
8 & Neck circumference & 19.0 & 20.1 & 22.0 & 23.0 & 24.0 & 25.2 & 25.5 & 23.1 & 1.4 \\
9 & Neck length & 3.0 & 3.0 & 3.5 & 4.0 & 4.6 & 6.0 & 6.0 & 4.2 & 0.8 \\
10 & Chest breadth & 14.0 & 14.1 & 15.7 & 16.0 & 16.5 & 19.0 & 19.5 & 16.2 & 1.1 \\
11 & Chest depth & 9.5 & 9.8 & 10.6 & 12.3 & 13.0 & 14.5 & 14.5 & 11.9 & 1.4 \\
12 & Chest circumference & 42.0 & 42.8 & 47.1 & 49.3 & 51.0 & 52.2 & 52.4 & 48.7 & 2.6 \\
13 & Shoulder height seated & 25.6 & 25.8 & 29.0 & 30.8 & 32.5 & 35.5 & 36.0 & 30.7 & 2.5 \\
14 & Shoulder breadth & 17.5 & 17.8 & 20.5 & 22.1 & 23.2 & 25.4 & 24.0 & 21.9 & 2.0 \\
15 & Shoulder depth & 4.6 & 4.8 & 5.1 & 5.6 & 5.8 & 6.4 & 7.1 & 5.8 & 1.3 \\
16 & Shoulder to elbow & 12.3 & 13.2 & 15.0 & 16.0 & 17.0 & 18.0 & 18.0 & 16.0 & 1.4 \\
17 & Back of elbow to fingertip & 20.3 & 20.3 & 22.0 & 22.6 & 24.0 & 25.9 & 26.6 & 22.9 & 1.5 \\
18 & Waist breadth & 12.5 & 13.1 & 14.9 & 16.0 & 17.0 & 18.7 & 19.5 & 15.9 & 1.5 \\
19 & Waist circumference & 24.0 & 24.8 & 42.0 & 45.9 & 48.0 & 50.6 & 51.4 & 43.7 & 6.9 \\
20 & Rump to knee length & 17.5 & 18.3 & 21.0 & 22.8 & 26.0 & 28.9 & 30.0 & 23.4 & 3.2 \\
21 & Knee to sole length & 18.0 & 19.1 & 22.0 & 22.5 & 24.1 & 26.7 & 27.0 & 22.9 & 2.1 \\
22 & Foot length & 12.0 & 12.1 & 13.2 & 14.0 & 15.0 & 15.7 & 16.0 & 14.1 & 1.0 \\
23 & Foot breadth & 5.0 & 5.6 & 6.5 & 7.0 & 7.2 & 9.0 & 9.0 & 7.0 & 0.9 \\
\hline & & & & & & & & &
\end{tabular}


[11]-[13], mid upper arm circumference [11] and head circumference [14] used for medical studies. Table 2 compares some dimensions of three year old child anthropometry with the data reported in the previous studies. It is clear that, the stature obtained in the present study was closer to what was reported in other works. Head circumference and chest circumference values for the present study were found to be closer to the values reported by other works. The low weight of Nigerian child was confirmed by Aina et al. [11] who found the mean weight of 30 months Nigerian children as $10.3 \mathrm{~kg}$. He concluded that the weight of the child was not up to the ideal according to World Health Organization (WHO) standard. Although climatic, nutritional, and economic factors are significantly different in different populations and countries, one of the important factors contributing to anthropometric differences is race or ethnicity.

\subsection{Anthropometric Comparison of 3 YO Nigerian Child and US Data from Snyder}

Table 3 shows that, 3YO child dimensions reported by Snyder were higher than 3YO Nigerian child in head breadth, length, and height, neck breadth and foot breadth. The overall results show that Snyder 3YO child dimensions deviate from that of $50^{\text {th }}$ percentile 3 YO Nigerian child in all dimensions. Remarkable difference can

Table 2. Anthropometric data of three-year-old Nigerian child in comparison with other studies.

\begin{tabular}{cccccccc}
\hline Author/year & Population & $\begin{array}{c}\text { Age } \\
(\text { months })\end{array}$ & $\begin{array}{c}\text { Number } \\
\text { Of subject }\end{array}$ & $\begin{array}{c}\text { Stature } \\
(\mathrm{cm})\end{array}$ & $\begin{array}{c}\text { Weight } \\
(\mathrm{kg})\end{array}$ & $\begin{array}{c}\text { Head Circ. } \\
(\mathrm{cm})\end{array}$ & $\begin{array}{c}\text { Chest Circ. } \\
(\mathrm{cm})\end{array}$ \\
\hline Aina et al. 2001 $[11]$ & Nigeria & 30 & 16 & 85.00 & 10.3 & & \\
Ebomoyi et al. (2012) $[13]$ & Nigeria-Yoruba & 36 & 42 & 82.22 & 13 & 48.5 & 51 \\
Oladipo et al. (2013 $[15]$ & Nigeria-Ikwerre & 36 & 48 & & & 49.94 & \\
Current study & Nigeria-Hausa & $\mathbf{3 0 ~ - 4 2}$ & $\mathbf{3 0}$ & $\mathbf{8 7 . 0}$ & $\mathbf{1 2}$ & $\mathbf{4 8 . 3}$ & $\mathbf{4 9 . 3}$ \\
\hline
\end{tabular}

Table 3. Comparison of 3YO Nigerian child dimensions with Snyder, 1977.

\begin{tabular}{|c|c|c|c|}
\hline Dimension & $\begin{array}{c}3 \text { YO Nigeria child } \\
50^{\text {th }} \text { Percentiles }(2.5 \text { - } 3.5 \text { years })\end{array}$ & $\begin{array}{l}3 \text { YO from Snyder }[10] 50^{\text {th }} \\
\text { Percentiles }(2.0-3.5 \text { years })\end{array}$ & $\%$ difference \\
\hline Weight & 12.0 & 14.1 & -14.9 \\
\hline Height & 87.0 & 93.4 & -6.9 \\
\hline Head breadth & 13.5 & 13.4 & +0.7 \\
\hline Head length & 18 & 17.5 & +2.9 \\
\hline Head height & 19 & 17.3 & +9.8 \\
\hline Head circumference & 48.3 & 49.5 & -2.4 \\
\hline Neck breadth & 8.5 & 7.1 & +19.7 \\
\hline Neck circumference & 23.0 & 23.8 & -3.4 \\
\hline Chest breadth & 16.0 & 16.1 & -0.6 \\
\hline Chest circumference & 49.3 & 50.7 & -2.8 \\
\hline Shoulder height seated & 53.2 & 54.4 & -2.2 \\
\hline Shoulder breadth & 22.1 & 24.4 & -9.4 \\
\hline Shoulder to elbow & 16.0 & 18.5 & -13.5 \\
\hline Back of elbow to fingertip & 22.6 & 24.4 & -7.4 \\
\hline Waist breadth & 16.0 & 19.1 & -16.2 \\
\hline Waist circumference & 45.9 & 48.1 & -4.6 \\
\hline Rump to knee length & 22.8 & 28.4 & -19.7 \\
\hline Knee to sole length & 22.5 & 27.0 & -16.7 \\
\hline Foot length & 14.0 & 14.7 & -4.8 \\
\hline Foot breadth & 7.0 & 6.0 & +16.7 \\
\hline
\end{tabular}


be seen in weight and height. Weight of 3YO Nigerian child was found to be less than the $14.1 \mathrm{~kg}$ reported by Snyder. Greater difference was noticed in rump to knee, knee to sole length, shoulder to elbow and waist breadth with more than $10 \%$ difference each. The dimensions of $3 Y$ O Nigerian child appeared to be within $20 \%$ lower than US data. It is evident from Table 1 that, only about $25 \%$ of 3 YO NC was taller than the 3YO United States child.

\subsection{Anthropometric Comparison of 3YO Nigerian Child and 3 YO HIII and Q3s Dummies}

The $50^{\text {th }}$ percentiles being the size dimensions representing average child in a population were considered in crash dummy design. Comparison of $3 Y O$ Nigerian child anthropometry and crash dummies was based on the $50^{\text {th }}$ percentile as shown in Table 4 . The percentage difference was evaluated as:

$$
\text { Percentage difference }=\frac{3 \text { YO Nigerian child data }- \text { Child dummy data }}{\text { Child dummy data }} \times 100
$$

Apart from head depth, foot breadth and waist circumference, the 3YO HIII and Q3s dummies are bigger than $50^{\text {th }}$ percentiles Nigerian child in all dimension measured. This difference can have an effect on the sitting posture in child seat. Chest depth and shoulder breadth dimensions of 3YO HIII and Q3s dummy were higher than that of Nigerian child with a difference of over $9 \%$ and this could have affected the restraint belt position on the child body. In general the two crash dummies were bigger than $3 Y O$ Nigerian child by a maximum difference of about $25 \%$.

A significant difference can be seen between the two crash dummies and 3YO Nigerian child (3YO NC). Great difference is observed in the total body weight, in which average Nigerian child was found to be about $25.8 \%$ and $16.1 \%$ lower than the two age matched crash dummies (3YO HIII and Q3s). The 3YO HIII ATD was greater than the weight maximum value of Nigerian child as seen in Table 1, which suggests that none of 3YO NC have weight greater than 3YO HIII. The weight of Q3s dummies was greater than $75^{\text {th }}$-percentiles of 3 YO NC. Since weight affect occupant kinematics during crash, Nigerian child is expected to have different kinematics from crash dummies under the same impact condition. Q3s were about $12 \%$ taller than $3 Y O$ NC and its height corresponds to $95^{\text {th }}$ percentiles while 3 YO HIII was higher than 3 YO NC by $8.0 \%$. These differences in stature between $3 \mathrm{YO}$ NC and crash dummies may affect the child head position relative to the child seat and contact points of the head with vehicle interior during crash event.

Table 4. Comparison of 3YO Nigerian child with 3YO HIII and Q3s dummies sizes.

\begin{tabular}{|c|c|c|c|c|c|}
\hline Anthropometry & $\begin{array}{c}3 \text { YO Nigeria } \\
\text { (3YO NC) child } 50^{\text {th }}\end{array}$ & $\begin{array}{l}\text { Hybrid III } 3 \text { YO } \\
\text { (HIII 3YO) [16] }\end{array}$ & $\begin{array}{l}\text { Q3s-dummies } \\
\text { (Q3s) [8] }\end{array}$ & $\begin{array}{c}\% \text { difference } \\
3 \text { YO NC Vs } \\
\text { H III } 3 \text { YO }\end{array}$ & $\begin{array}{c}\text { \% difference } \\
\text { 3YO NC Vs Q3s }\end{array}$ \\
\hline Stature & 87.0 & 94.5 & 98.6 & -7.9 & -11.8 \\
\hline Weight & 12.0 & 16.17 & 14.3 & -25.8 & -16.1 \\
\hline Head breadth & 13.5 & 13.6 & 13.8 & -0.7 & -2.2 \\
\hline Head depth & 18 & 17.5 & 18.0 & +2.9 & 0 \\
\hline Head circumference & 48.3 & 50.8 & 50.2 & -4.9 & -3.8 \\
\hline Chest breadth & 16.0 & - & 17.4 & - & -8 \\
\hline Chest depth & 12.3 & 14.6 & 15.1 & -15.8 & -18.5 \\
\hline Chest circumference & 49.3 & 54.0 & 52.3 & -8.7 & -5.7 \\
\hline Shoulder height seated & 30.7 & 31.5 & 34.0 & -2.5 & -9.7 \\
\hline Shoulder breadth & 22.1 & 24.4 & 24.7 & -9.4 & -10.5 \\
\hline Shoulder to elbow & 16.0 & 19.3 & 18.6 & -17.1 & -14 \\
\hline Back of elbow to fingertip & 22.6 & 25.5 & 24.0 & -11.4 & -5.8 \\
\hline Waist circumference & 45.9 & 54.0 & 52.1 & -15.0 & +11.9 \\
\hline Rump to knee length & 22.8 & 29.2 & 30.5 & -21.9 & -25.2 \\
\hline Knee to sole length & 22.5 & 27.2 & - & -17.3 & - \\
\hline Foot length & 14.0 & 14.3 & - & -2.1 & - \\
\hline Foot breadth & 7.0 & 5.9 & - & +18.6 & - \\
\hline
\end{tabular}

-dimension not available. 
The European mass classification of child seat do not seems to be relevant for Nigerian child because the seatbelt appears as badly designed for this population according to anthropometric data obtained in this study even if they are seated in the good CRS, regarding their weight and stature. Though it was reported that fat children are vulnerable to high injuries [17], the injury potential and safety performance of CRS for Nigerian child that were generally lower than crash dummies need to be investigated using the size matched crash dummies. The two crash dummies differ slightly in size because they were produced by different companies and using anthropometric data of different populations. Child seats are designed to cover range of children weight, but their performances were only evaluated for $50^{\text {th }}$ percentile child weight with the expectation that it will cover other percentiles. Considering the injuries sustained by younger ones in road traffic, a more detailed validation need to be carried out using the various percentiles in order to alleviate the blind assumption associated with selecting single size to represent whole population. Also apart from weight and stature other anatomical geometry such as chest depth and shoulder breadth are critical to restraint system design and judgement for children. Difference in stature can lead to different belt routings for the same harness position which causes higher neck and head injury risk. Going by the differences in anthropometric dimensions, three year old Nigerian will occupy different position from that of $3 \mathrm{YO}$ HIII and Q3s dummies. The sample size used in the current study was noted to be rather small and not sufficient to make general conclusions for anthropometric assessment representing Nigerian children, but it is our belief that the measured sizes were enough to justify efforts to improve vehicle safety for Nigerian children.

\section{Conclusion}

The anthropometric dimensions of three-year-old Nigerian child have been measured and analysed in this study. The data were compared with United States three-year-old anthropometric data gathered by Snyder, where the $50^{\text {th }}$ percentile Nigerian child was found to be smaller than $50^{\text {th }}$ percentile US child in some of the dimensions compared. This is an indication of possible mismatch between three-year-old Nigeria child and product such as child restraint seat and crash dummies produced based on the US data. Three-year-old Nigerian child was further compared with the dimensions of crash dummies in which it was found to be smaller with a maximum difference of $-25.8 \%$ and $-25.2 \%$ for 3 YO HIII and Q3s dummies respectively. The difference was significantly high in the two reference dimensions: weight and stature, which indicated that the current crash dummies were not valid for three-year-old Nigerian children. This study will provide immense contribution in the product design and development of crash dummies for Nigerian children. The data presented here, can be used to develop numerical child body model using scaling technique. Also, the data could be used for improvement of vehicles and CRS designs.

\section{Acknowledgements}

The authors wish to thank Universiti Putra Malaysia for the facilities and Bayero University Kano, Nigeria for the financial support of the first author. In addition, this work was also supported by Fundamental Research Grant Scheme with Reference Number: FRGS/2/2013/TK01/UPM/01/1, vot 5524355, Ministry of Education (MOE), Malaysia, and was carried out in Universiti Putra Malaysia (UPM). The authors therefore would like to record their thanks to the MOE and UPM for the supports.

\section{References}

[1] Klinich, K.D. and Reed, M.P. (2013) Pediatric Injury Biomechanics. Pediatric Anthropometry, 1-31.

[2] Serre, T., Lalys, L., Brunet, C., Bartoli, C., Christia-Lotter, A. and Leonetti, G. (2006) 3 and 6 Years Old Child Anthropometry and Comparison with Crash Dummies. SAE Technical Paper.

[3] Cao, L., Zhang, K., Lv, X. and Yan, L. (2015) Comparison of Current ATDs with Chinese Adults in Anthropometry. Traffic Injury Prevention, 9588.

[4] Reed, M.P. and Rupp, J.D. (2013) An Anthropomorphic Comparison of Current ATDs with the US Adult Population. Traffic Injury Prevention, 14, 703-705. http://dx.doi.org/10.1080/15389588.2012.752819

[5] BE FORWARD (2016) Cars per Capita in Africa-Which Country Has the Most Cars on the Road? http://blog.beforward.jp/regional-topics/africa/cars-capita-africa-country-cars-road.html

[6] National Highway Traffic Safety Administration (2014) Traffic Safety Facts, Children, 2012. Data DOT HS 812011. 
[7] World Health Organization (WHO) (2013) Road Safety in the WHO African Region the Facts 2013.

[8] Wismans, J., Waagmeester, K., Le Claire, M., Hynd, D., de Jager, K., Palisson, A. and Trosseille, X. (2008) Q-Dummies Report: Advanced Child Dummies and Injury Criteria for Frontal Impact.

[9] Pellow, D. (1996) Hausa. Encyclopedia of World Cultures. http://www.encyclopedia.com/topic/Hausa.aspx

[10] Snyder, R.G., Schneider, L.W., Owings, C.L., Reynolds, H.M., Golomb, H. and Schork, A. (1977) Anthopometry of Infants, Children and Youth to Age 18 for Product Safety Design. Measurement, Final Report.

[11] Aina, O.F. and Morakinyo, O. (2001) Anthropometric Assessments in Nigerian Children. East African Medical Journal, 78, 312-316. http://dx.doi.org/10.4314/eamj.v78i6.9025

[12] Senbanjo, I.O., Oshikoya, K.A., Olutekunbi, O.A. and Njokanma, O.F. (2013) Body Fat Distribution of Children and Adolescents in Abeokuta, Southwest Nigeria. American Journal Physical Anthropology, 150, 647-654. http://dx.doi.org/10.1002/ajpa.22241

[13] Ebomoyi, E.W. (2012) Ethnic Differences in the Nutritional Status of Nigerian Rural Fulani, Hausa and Yoruba School-Age Children and the Role of Bio-Fortification to Alleviate Protein Energy Malnutrition. Journal of Basic and Applied Scientific Research, 2, 7287-7296.

[14] Osunwoke, E. and Didia, B. (2012) A Study on the Normal Values of Inner Canthal, Outer Canthal, Interpupillary Distance and Head Circumference of 3-21 Years Ijaws. American Journal of Scientific and industrial Research, 3, 441445. http://dx.doi.org/10.5251/ajsir.2012.3.6.441.445

[15] Oladipo, Gabriel, S., et al. (2013) Measurements of Head Circumference, Intercanthal Distances, Canthal Index and Circumference Interorbital Index of Ikwerre School Children in Nigeria. Journal Natural Sciences Research, 3, 16-21.

[16] Mizuno, K., Iwata, K., Deguchi, T., Ikami, T. and Kubota, M. (2005) Development of a Three-Year-Old Child FE Model. Traffic Injury Prevention, 6, 361-371. http://dx.doi.org/10.1080/15389580500255922

[17] Kim, J.E., Hsieh, M.H., Shum, P.C., Tubbs, R.S. and Allison, D.B. (2015) Risk and Injury Severity of Obese Child Passengers in Motor Vehicle Crashes. Obesity, 23, 644-652. http://dx.doi.org/10.1002/oby.21018

\section{Submit or recommend next manuscript to SCIRP and we will provide best service for you:}

Accepting pre-submission inquiries through Email, Facebook, Linkedin, Twitter, etc A wide selection of journals (inclusive of 9 subjects, more than 200 journals)

Providing a 24-hour high-quality service

User-friendly online submission system

Fair and swift peer-review system

Efficient typesetting and proofreading procedure

Display of the result of downloads and visits, as well as the number of cited articles

Maximum dissemination of your research work

Submit your manuscript at: http://papersubmission.scirp.org/ 